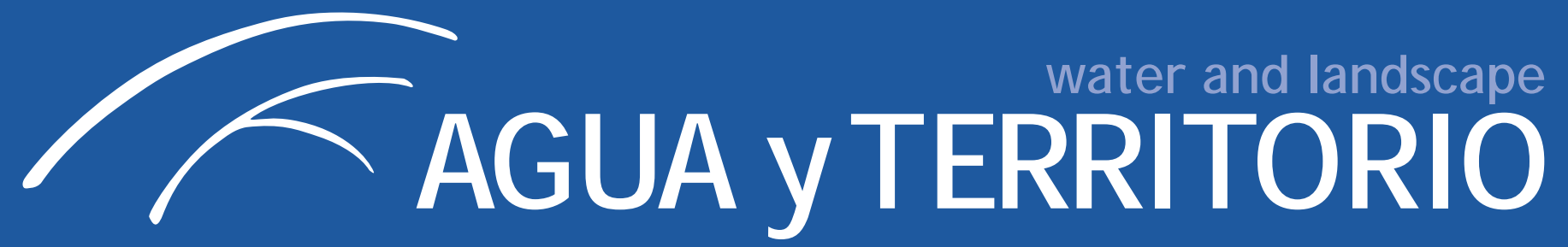

\title{
Agua útil, aguas milagrosas de la Capitanía de Minas Gerais (siglo XVIII)
}

\author{
Água úteis, águas milagrosas na capitania de Minas Gerais (sec. XVIII) \\ Useful Water, Miraculous Waters in the Captaincy of Minas Gerais (18 ${ }^{\text {th }}$ Century) \\ Júnia Ferreira-Furtado \\ Universidad Federal de Minas Gerais, Belo Horizonte, Brasil. juniaf@ufmg.br
}

\begin{abstract}
Resumen - Este artículo analiza algunos aspectos de la interacción entre el hombre y las aguas de la capitanía de Minas Gerais, región sureste de Brasil, a lo largo del siglo XVIII. Primeramente aborda la necesidad que tuvieron las ciudades, que estaban siendo construidas, de retener el agua, con la finalidad de permitir la minería y garantizar el abastecimiento de hombres y animales. En segundo lugar investiga el uso medicinal del agua, poniendo como centro de estudio el caso de las aguas milagrosas de Lagoa Santa, Laguna Santa, que se encuentra cerca de la Villa de Sabará.

Resumo - Esse artigo analisa al guns aspectos da interação entre os homens e as águas no espaço da capitania de Minas Gerias, na região sudeste do Brasil, ao longo do século XVIII. Primeiramente, aborda a necessidade de contenção das águas nas cidades que eram edificadas na capitania, com o intuito de permitir a mineração e garantir 0 abastecimento de homens e animais. Em segundo lugar, investiga e se centra no aproveitamento medicinal da água, recortando o caso particular das águas milagrosas da chamada Lagoa Santa, situada nas proximidades da vila de Sabará.

Abstract - This article examines some aspects of the interaction between humans and water resources within the captaincy of Minas Gerais, in southeastern Brazil, throughout the eighteenth century. First, it addresses the need to make water available in the captaincy's emerging urban settlements in order to supply the mining industry, people and animals. Secondly, the research lays special emphasis on the medicinal use of water, analyzing in particular the case of the miraculous waters of Lagoa Santa, a lagoon located near the town of Sabará.
\end{abstract}

Palavras-chave: água, rios, Minas Gerais, águas urbanas, medicina Palabras clave: aguas, ríos, Minas Gerais, aguas urbanas, medicina Keywords: water, rivers, Minas Gerais, urban waters, Medicine 